\title{
STUDYING THE HISTORY OF THE SLAVIC STISHNOY PROLOGUE: NEW OPPORTUNITIES AND PROSPECTS ${ }^{\star}$
}

\author{
Реu. на: Петков Г., Спасова М. Търновската редакция на Стишния \\ Пролог. Текстове. Лексикален индекс : в 12 т. - Пловдив : \\ Паисий Хилендарски, 2008-2014.
}

Rev. of: Petkov, G., Spasova, M. (2008-2014). T"rnovskata redaktsiya na Stishniya

Prolog. Tekstove. Leksikalen indeks v 12 t. [The Turnovo Stishnoy Prologue

Edition. Texts. Lexical Index. 12 Vols.]. Plovdiv, Paisii Khilendarski.

Olga Shcheglova

Novosibirsk State University,

Novosibirsk, Russia

In this review, the author analyses the Tarnovo Edition of the Stishnoy Prologue. Texts: Lexical Index (published by Bulgarian researchers Georgi Petkov and Maria Spasova) and focuses on the structure of the publication, providing a detailed description of the parts of each volume: prologue texts, prologue poems, the lexical index, and the index of saints' names. The review evaluates the work from the point of view of its academic contribution. The reviewer largely agrees with the authors' point of view on the history and the study of the Stishnoy Prologue set forth in the preface to the publication. While objecting to some points, the reviewer evaluates the work highly, considering it an important stage in the process of studying the history of the Stishnoy Prologue, one of the most widespread hagiographic calendar collections of the Middle Ages. The publication of the texts of the Stishnoy Prologue, even those in just the Tarnovo edition, can be a powerful catalyst for further textual criticism and linguistic studies of the numerous Russian, Serbian, and Bulgarian copies that have survived to the present day. Ultimately, the reviewed publication can become the basis for a full-scale critical edition of the Stishnoy Prologue. The review emphasises the timeless significance of this publication for Slavic studies, its innovative character, its structural integrity, its theoretical sophistication, and the enormous practical importance of the work for Bulgarian philologists.

Keywords: Stishnoy Prologue; edition; prologue texts; prologue verses; names of saints, lexical index.

* Citation: Shcheglova, O. (2020). Studying the History of the Slavic Stishnoy Prologue: New Opportunities and Prospects. In Quaestio Rossica. Vol. 8, № 1. P. 297-305. DOI 10.15826/qr.2020.1.463.

Цитирование: Shcheglova O. Studying the History of the Slavic Stishnoy Prologue: New Opportunities and Prospects // Quaestio Rossica. Vol. 8. 2020. № 1. P. 297-305. DOI 10.15826/qr.2020.1.463.

(C) Щеглова О., 2020

Quaestio Rossica • Vol. $8 \cdot 2020$ • № 1, p. 297-305 
В рецензии на издание болгарских исследователей Георгия Петкова и Марии Спасовой «Тырновская редакция Стишного пролога. Тексты. Лексический индекс» основное внимание концентрируется на структуре книги. Подробно описываются составные части каждого тома (собственно проложные тексты, проложные стихи, лексический индекс и индекс имен святых), оценивается их научная значимость. Рецензент во многом согласен с точкой зрения авторов на историю изучения и саму историю Стишного Пролога, изложенную в предисловии к книге. Высказывая отдельные несущественные замечания, автор дает высокую оценку данному изданию, определяя его как событие и определенный важный этап в процессе изучения истории текста Стишного Пролога - одного из распространенных агиографических календарных сборников Средневековья. Выход в свет текстов Стишного Пролога даже в одной Тырновской редакции способен стать мощным катализатором дальнейших текстологических и лингвистических исследований многочисленных русских, сербских и болгарских списков, сохранившихся до настоящего времени. В конечном итоге рецензируемое издание может стать основой полномасштабного критического издания Стишного Пролога. В статье подчеркиваются непреходящее значение этого издания для славистической науки, новаторский характер, структурная целостность, высокий теоретический уровень и огромная практическая значимость труда болгарских филологов.

Ключевые слова: Стишной Пролог; редакция; проложные чтения; проложные стихи; имена святых; лексический индекс.

"The harvest is plentiful, but the labourers are few..." (Matt. $9: 36-38$ ). These Gospel lines come to mind when you look at the publication of the texts of the Stishnoy Prologue prepared by two Bulgarian researchers, Georgi Petkov and Maria Spasova. The importance of this publication is difficult to overestimate. How many more manuscripts are stored in the ancient depositories of not only our country, but others, that have only been seen by the staff of archive departments, remaining untouched by researchers? Unfortunately, there are not many modern researchers and philologists who study both the literary and linguistic aspects of Slavic manuscript heritage. But without the knowledge of how our ancestors read and how the literary language of our culture was formed, we believe it is difficult to discuss modern trends in these areas. Even more respect is due to this edition because it offers an idea about the history of old Bulgarian literature and language, discusses the cultural ties of medieval Bulgaria, Serbia, and Russia, and reveals the system of Christian values formed by hagiographic collections in the Slavia Orthodoxa. It shows the links and continuity of Byzantine and Slavic culture, while introducing into academic circulation a large number of medieval texts that have been insufficiently studied.

This peer-reviewed edition contains readings of the Stishnoy Prologue for each month of the church year, starting in September. The Stishnoy Prologue is a hagiographic calendar translated from Greek in the first 
half of the $14^{\text {th }}$ century. Originally, the Stishnoy Prologue was to be read during services, which predetermined the literary features of the Prologue's hagiographies: namely, brevity, a didactic character, and accessibility of presentation. At the same time, the prologue should not be considered a mechanical reduction of extensive hagiographies. The Stishnoy Prologue became one of the most popular written artefacts among the Slavs, and was distributed in many copies that have survived to this day ${ }^{1}$. Among the southern Slavs, it mostly replaced the simple Prologue; in medieval Russia, it existed alongside the simple Prologue until the $17^{\text {th }}$ century.

The Stishnoy Prologue was not initially studied separately from the Prologue, since a widely accepted opinion held that the Prologue (simple, non-Stishnoy) and the Stishnoy Prologue were two varieties of one monument-Prologue, and the difference between these variations is only in the presence or absence of a distich or tercet preceding the prologue's article. However, studies over the last two decades (in particular, those of G. Petkov) show that the Prologue and the Stishnoy Prologue are different artefacts in terms in their time of origin, their features in Slavic literature, and their structural characteristics, although it is also necessary to note identical principles in their drafting and extensive similarities between them [Петков]. The study of the Stishnoy Prologue in literary and linguistic terms is predominated by the work of Bulgarian researchers and, to a lesser extent, Russian scholars, including the works of this reviewer.

The composition of the Stishnoy Prologue is constituted by short hagiographies: these are preceded in most cases by poems, as well as a few short stories about church holidays and events, arranged in accordance with the Jerusalem Charter in the calendar. The edition under review was prepared as a series of 12 books, each of which has the same structure. First appear the hagiographies for each month. They are followed by the poems, translated into modern Bulgarian. Then comes a lexical index, which presents all the word forms found in the texts of the month. The publication is completed by Bulgarian-Greek and Greek-Bulgarian indices of saints' names from the monthly texts. In the first volume, G. Petkov provides a preface in which he briefly describes the history of scholarship on the Stishnoy Prologue, the history of its various editions, and the sources used for comparison with the Tarnovo edition. He explains the structure and principles in the publication and outlines avenues for further research.

As the sources of this edition, the authors used two of the oldest Bulgarian copies. The first is from the library of the Bulgarian Academy of Sciences, dated 1368-1370, for September-February (BAN73). The second is from the library of the Zografsky Monastery, dated 1345-1360, for MarchAugust (Zogr. 80). These lists, according to Petkov, make up the full circle of readings in the Tarnovo Stishnoy Prologue. The creation of a Stishnoy Prologue in Tarnovo in the first half of the $14^{\text {th }}$ century is considered one

${ }^{1}$ We know of more than 60 copies of the Stishnoy Prologue for the winter half of the year and more than 40 containing readings for the summer half of the year. 
of the highest achievements of the Tarnovo school. The Tarnovo Stishnoy Prologue became widespread and formed the basis of Serbian and Russian editions. Its distinctive feature is the presence of the so-called Tarnovo hagiography cycle: the lives of Paraskeva Tarnovo (14 October), St John of Rila (19 October), Hilarion Meglenskiy (21 October), and Michael the Warrior (22 November).

This publication's scholarly value lies in the fact that it is based on the results of hagiographic and textual research on the oldest Bulgarian, Serbian, and Russian manuscripts, undertaken by G. Petkov and published in 2000 [Петков]. In preparation for this publication, a comparative reading was made of the prologue texts of the Tarnovo Stishnoy Prologue while using the most senior and precisely dated Serbian and Russian lists.

The Serbian manuscripts used were: No. 34 from the collection of Nikolac Monastery in Montenegro, 1360-1370, for September-December (Nick. 34); No. 55 from the collection of the Dechan Monastery, 13601380, for December-February (Dech. 55); and No. 1040 from the collection of the Bulgarian People's Library of Ss Cyril and Methodius in Sofia, 13471356, for March-August (NBMK-1040). These three copies contain the composition of the Lukiev Stishnoy Prologue.

The Russian copies are from three manuscripts in the collection of the Holy Trinity-St. Sergius Lavra (Russian State Library): No. 717, 1429, for JuneOctober (TSL, s. 304, 717); No. 720, $15^{\text {th }}$ century, for November-February (TSL, s. 304, 720); and No. 715, 1429 for March-May (TSL, s. 304, 715). They contain the Moscow Stishnoy Prologue. Four other manuscripts, three of which are in St Petersburg (Russian State History Archive, s. 834), contain the Novgorod Stishnoy Prologue: No. 3933, 1479, for September-November (Syn., s. 834); No. 3934, 1475-1476, for December-February (Syn. s. 834); and No. 1267, 1477-1478, for June-August (Syn., s. 834). One manuscript is from the Russian National Library: F. I. 683, $15^{\text {th }}$ century, for March-May (RNL, F. I.).

Textual criticism of the manuscripts allows us to see the following differences in composition: the addition of Russian, Bulgarian, and Serbian prologue texts and the addition of words, phrases, and omissions in the prologue's hagiographies, readings, poems, individual lexemes, and phrases. All identified discrepancies are given after the prologue texts in the section "Discrepancies and notes". In addition, this section notes lexical and morphological-syntactic discrepancies, including some interesting differences in the writing of anthroponyms and place names. The system for presenting discrepancies is well thought out: the page of the publication and the line in which the discrepancy is located are indicated; the letters $\mathrm{L}, \mathrm{M}$, and $\mathrm{H}$ indicate the comparable editions; the discrepancy itself is given; and notes are provided about the absence or addition of a word or phrase or text. The hierarchy of discrepancies are differentiated in Serbian manuscripts by the Lukiev edition (L), the Moscow edition (M), and finally the Novgorod edition $(\mathrm{H})$.

The presence of the section "Discrepancies and notes" is of undoubted scholarly value. Familiarity with the discrepancies in the oldest Serbian and 
Russian copies gives a clear idea of the full composition of the Tarnovo Stishnoy Prologue, making it possible to see how the texts of this artefact were perceived within the Serbian and Russian manuscript traditions. The discrepancies contain added readings, including the title, beginning, and end of the hagiography or words, meaning they can be used in subsequent studies of the Tarnovo Stishnoy Prologue within the Russian manuscript tradition. Petkov identified the most important discrepancies of the winter half, while M. Spasova conducted linguistic readings of texts and comparisons with the main list of the summer half of Zogr. 80.

It should be noted that in Zogr. 80, there are no sheets at the beginning, middle, and end of the manuscript. Therefore, in order to obtain a complete picture of the composition of the everyday corpus of the Stishnoy Prologue's summer half, the compilers used texts from the Russian manuscript TSL-715. The Serbian manuscript NBKM No. 1040 could not be used to fill the missing gaps of Zogr. 80, as it contains no readings for the whole of March and has gaps in other months of the summer; furthermore, there are no readings from 10 to 31 August. In these cases, discrepancies are given only in the Russian manuscript. The text cited in TSL-715 is given in square brackets. We learn about this nuance on page 93 of volume VII with the March readings; this background information is not provided in the preface. We believe that it would have been good to give a list of the dates and readings missing in Zogr. 80 and replaced by texts from TSL-715, especially since the square brackets do not stand out in the text and the reader can experience difficulties when finding a replaced text's location.

The second part of the publication contains the prologue's verses. It presents the texts of poems and their translation into modern Bulgarian language separately. But it should be noted that this is only present in the first six volumes of the publication. As the authors write, 'the summer half-year translation of proofs into modern Bulgarian is not included, as it will be published in the second volume' (Византийските проложни стихове с именник на християнските имена (в превод на старобътгарски от XIV и превод на съвременен български език)): this will be 'co-edited and translated by Iv. Hristov, M. Spasova and G. Petkov’ [Петков, Спасова, т. 7, с. 4].

Nevertheless, the separate publication of the prologue's verses, read in September-February, has great scholarly significance. The study and publication of the poems were started by Italian researchers [Cresci, Skomorochova Venturini]. The prologue's verses are presented for the whole year [Петков, с. 233-446]. According to the authors, the publication of the poems with their translation into modern Bulgarian enables the reader to learn more about the poetic culture of the old Bulgarian scribes. For researchers, this publication offers rich material for further in-depth study of the prologue's poems.

The third part of each book, the lexical index, is of great interest, particularly for future linguistic research. In the index, lexemes are presented in alphabetical order without grammatical characteristics and without the initial form of the lexeme. After the lexeme, the frequency of use, the page on 
which it is published, and the line where the word is located are all indicated in brackets. For example, 'слоугы (5) $8: 23,12: 20,15: 8,48: 8,74: 28$ ' [Петков, Спасова, т. 7, с. 244]. This setup is very convenient for context searches and lexical analysis. An index of lexemes for even one hagiographic collection undoubtedly demonstrates the richness of the literary language of the middle Bulgarian period. Each volume indicates the number of lexemes found in the texts and the number of their word usage. For example, the September lexical index contains 7,701 lexemes in 20,563 variants of word usage. Edited by M. Spasova, the lexical index of each volume has been prepared via a computer program developed by $\mathrm{D}$. Blagoev.

After the release of vol. 12, the authors will work on vol. 13, a dictionary that will include all the vocabulary of the Tarnovo Stishnoy Prologue. The dictionary will be developed in accordance with generally accepted lexicographical principles [Там же, c. 100]. I would very much like to see the authors fulfil their plans.

The last part of each book is an index listing the names of the saints for the month in two forms. The Bulgarian-Greek and Greek-Bulgarian indices include the names of the saints from the texts of the month, which have a prologue's poem and hagiography, only a prologue's poems, or only a prologue's life and title. The names are listed in alphabetical order. When more than one name appears in the header, each name following the first refers to it. In the Bulgarian-Greek index, names are given in Bulgarian, old Bulgarian, and Greek. After these, brackets mark which prologue text is available for the corresponding saint : verses, verses and life, life, story, or title. At the end, the date of the month and the serial number of the prologue's text are indicated (the order of the readings throughout the month is consistent). For example: «Александър, папа Римски - Алек-

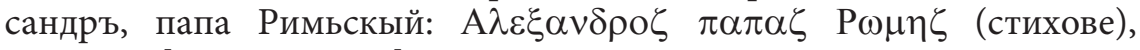
16.III.79» [Там же, с. 293].

In the second index, the names are arranged in alphabetical order in Greek, old Bulgarian, and modern Bulgarian, with appropriate pointers. The compilers of the index of the names of saints have done much hard work: all the names are checked against the indices in the books of Archbishop Sergius [Сергий (Спасский), с. 579-627], "Christianity. An Encyclopaedical Dictionary" [Христианство, с. 576-689], and another

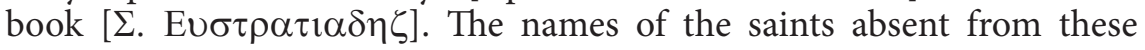
sources are marked with an asterisk.

The index was compiled by Dr. St. Kozarova (names of saints of September and names of saints in Greek for October-February), Iv. Christov (names of saints in Greek for March-May), and A. Tikhova (names of saints in Bulgarian and old Bulgarian for October-May and names of saints for June-August).

In the history of the Stishnoy Prologue, there are still many unresolved issues. In particular, disagreement exists regarding the number of transfers in the Stishnoy Synaxarion from Greek into the Slavic language. The authors of this publication accept the argument of Kl. Ivanova that the 
Stishnoy Prologue was distributed among the Slavic scribes in Bulgarian and Serbian translations [Иванова, с. 121-127; Петков, Спасова, т. 1, c. 9]. Additionally, more investigation is required into the history of the editions used for these translations into Serbian and Bulgarian; not long ago, scholars were interested in the prologue's verses, demonstrating that the history of the text of the Stishnoy Prologue requires further study. A virtually unexplored question appears in the relationships between the Stishnoy Prologue and the printed Prologue, as well as the Stishnoy Prologue and numerous handwritten service Mineas (holidays and monthly) that appeared in the Romanian principalities of Vlahia and Moldova from the end of $14^{\text {th }}$ century. These manuscripts, the second part after the service to the saints, present the readings of the Stishnoy Prologue for the corresponding month in the form that we find in the Tarnovo edition ${ }^{2}$.

It is necessary to study the relationship between the Stishnoy Prologue and the Great Menaion of Metropolitan Macarius. Further, there is little study into the linguistics of the Stishnoy Prologue. In light of the above, this edition is a first and very important step in the study of the complex textual history of the Stishnoy Prologue. To sufficiently study the history of the Stishnoy Prologue in medieval Russia and the wider Slavia Orthodoxa, many specialists must devote their efforts. In the report at the IX International Congress of Slavists, L. P. Zhukovskaya mentioned the importance and objectives of studying the Prologue: 'The Prologue is a set of problems that cannot be exhaustively studied even in several decades of intensive research in the field of Slavic manuscript heritage. After all, the Prologue in its origins and its centuries-old evolution was associated with an entire rich context of writing, including literature serving the needs of the Church, narrative literature itself, the "didactic" and specific collections of "sustainable content", such as "Chrysostom" [Жуковская, с. 111]. The authors of the edition under review also believe that a comprehensive study and subsequent critical edition of the Stishnoy Prologue is possible through the future collective efforts of specialists and medievalists. An exhaustive answer to all the unsolved questions in the history of the Stishnoy Prologue can be obtained only after studying all the surviving copies in their entirety.

For researchers of the Stishnoy Prologue, this edition, in our opinion, is just as valuable as the digitized written artefacts from the manuscript department of the Russian State Library, posted on the website of the Holy Trinity-St. Sergius Lavra. Unfortunately, the Tarnovo Stishnoy Prologue is a bibliographic rarity. The circulation of this edition is not specified, but it is thought that it was not great. Volumes 1-6 are the result of work on project OXH-305/2007, which was funded by the National Fund of Bulgaria, "Scientific research", MOH. As far as we know, the publication's completion is the result of the authors' personal efforts. The contribution of Bulgarian

${ }^{2}$ We know one such list from the collection of Undolsky in the manuscript department of the RSB: Mineya - Stishnoi Prolog na mai, 1577 g., moldavskii, 145 l [РГБ. Ф. 310 (Собр. В. М. Ундольского). № 82]. 
philologists to the study of Slavic manuscript heritage and, in particular, to the study of one of the most popular hagiographic calendar miscellany the Stishnoy Prologue - is invaluable. The Bulgarian scholars Georgi Petkov and Maria Spasova, along with their colleagues who worked on this edition (St. Kozarova, Iv. Christov and A. Tikhova), have made an important first step within the great task facing medieval studies: the study of the history of the Prologue on the basis of all the surviving copies in their entirety and the subsequent critical publication of the text. I consider this edition of my Bulgarian colleagues to be a highly professional work, the natural result of great collective practical and intellectual effort. Their well-deserved success represents a significant accomplishment both in the study of the heritage of Slavic manuscripts and in Slavic research.

\section{Список литературы}

Жуковская Л. П. Текстологическое и лингвистическое исследование Пролога (избранные византийские, русские и инославянские статьи) // Славянское языкознание : IX Междунар. съезд славистов (Киев, сентябрь 1983) : Доклады советской делегации. М. : Наука, 1983. С. 110-120.

Иванова Кл. Агиографската продукция на Търновската книжовна школа : дисертация за получаване на научната степен кандидат на филологическите науки. София : [Б. и.], 1979. $530 \mathrm{c.}$

Петков Г. Стишният Пролог в старата българска, сръбска и руска литература (XIV-XV век): Археография, текстология и издание на проложните стихове. Пловдив : Пловдивско унив. изд-во, 2000. 560 с.

Петков Г., Спасова М. Търновската редакция на Стишния пролог. Текстове. Лексикален индекс : в 12 т. Пловдив : Паисий Хилендарски, 2008-2014. Т. 1. Месец септември. 445 с. Т. 7. Месец март. 334 с.

РГБ. Ф. 310 (Собр. В. М. Ундольского). № 82.

Сергий (Спасский), архиеп. Полный Месяцеслов Востока : в 2 т. М. : Православная энциклопедия, 1997. Т. 1. Восточная агиология (репринт 2-го, доп. и испр. владимирского изд. 1901 г.). 768 с.

Христианство: энцикл. словарь: в 3 т. / гл. ред. С. С. Аверинцев. М. : Большая Рос. энцикл., 1993-1995. Т. 3.781 с.

Cresci L. R., Skomorochova Venturini L. I versetti del Prolog Stišnoj. Torino : Rosenberg \& Sellier, 1999. $322 \mathrm{p}$.

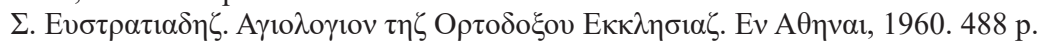

\section{References}

Averintsev, S. S. (Ed.). (1993-1995). Khristianstvo. Entsiklopedicheskii slovar' $v$ 3 t. [Christianity. Encyclopaedical Dictionary. 3 Vols.]. Moscow, Bol'shaya Rossiiskaya entsiklopediya. Vol. 3. 781 p.

Cresci, L. R., Skomorochova Venturini, L. (1999). I versetti del Prolog Stišnoj. Torino, Rosenberg \& Sellier. 322 p.

Ivanova, K1. (1979). Agiografskata produktsiya na T"rnovskata knizhovna shkola [The Hagiographic Production of the Tarnovo Literary School]. Disertatsiya za poluchavane na nauchnata stepen kandidat na filologicheskite nauki. Sofiya, S. n. 530 p.

Petkov, G. (2000). Stishniyat Prolog v starata b"lgarska, sr"bska i ruska literatura (XIV-XV vek). Arkheografiya, tekstologiya i izdanie na prolozhnite stikhove [The Stishnoy Prologue in Old Bulgarian, Serbian, and Russian Literature $\left(14^{\text {th }}-15^{\text {th }}\right.$ Centuries): Archaeography, Textology, and the Publication of Prologue Verses]. Plovdiv, Plovdivsko universitetsko izdatelstvo. $560 \mathrm{p}$. 
Petkov, G., Spasova, M. (2008-2014). T"rnovskata redaktsiya na Stishniya Prolog. Tekstove. Leksikalen indeks v 12 t. [The Turnovo Prologue Edition. Texts. Lexical Index. 12 Vols.]. Plovdiv, Paisii Khilendarski. Vol. 1. Mesets septemvri. 445 p. Vol. 7. Mesets mart. 334 p.

$R G B$ [Russian State Library]. Stock 310. (Sobranie V. M. Undol'skogo). № 82.

Sergii (Spasskii), Archb. (1997). Polnyi Mesyatseslov Vostoka v 2 t. [The Complete Menology of the East. 2 Vols.]. Moscow, Pravoslavnaya entsiklopediya. Vol. 1. Vostochnaya agiologiya (reprint vtorogo, dopolnennogo i ispravlennogo vladimirskogo izdaniya 1901 g.). 768 p.

Zhukovskaya, L. P. (1983). Tekstologicheskoe i lingvisticheskoe issledovanie Prologa (izbrannye vizantiiskie, russkie i inoslavyanskie stat'i) [Textual and Linguistic Study of the Prologue (Selected Byzantine, Russian, and Non-Slavonic Articles)]. In Slavyanskoe yazykoznanie. IX Mezhdunarodnyi s"ezd slavistov (Kiev, sentyabr' 1983). Doklady sovetskoi delegatsii. Moscow, Nauka, pp. 110-120.

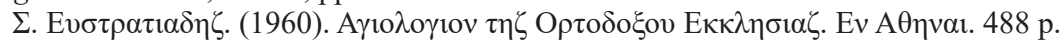

The article was submitted on 31.10.2018 